\title{
Synthesis, Characterization and Antimicrobial Studies of Ruthenium(II)Carboxylates with 3-Hydroxypyridine
}

\author{
Festus A. S. Fabiyi (Corresponding author) \\ Department of Chemistry and Industrial Chemistry, Bowen University, Iwo, Osun State Nigeria \\ E-mail: sunfabiyi@yahoo.com \\ Oluwafunke Lara Ibironke \\ Department of Chemistry and Industrial Chemistry, Bowen University, Iwo, Nigeria \\ Maria Luz Lopez \\ INQUIMAE, Departamento de Quimica Inorganica, Analytica y Quimica Fisica \\ Facultad de Ciencias Exactas y Naturales, Universidad de Buenos Aires, Argentina \\ E-mail: mluzlopez@yahoo.com.ar
}

Received: January 18, 2011 Accepted: February 10, 2011 doi:10.5539/ijc.v3n2p3

This research is financed by Bowen University, Iwo through award of Senate Research Grant

\begin{abstract}
Four new complexes, $\left.\left[\mathrm{Ru}\left(\mathrm{O}_{2} \mathrm{CCH}_{3}\right)_{2}(3-\mathrm{pyOH}){ }_{2}\right)\right]$ (1), $\left[\mathrm{Ru}_{2}\left(\mathrm{O}_{2} \mathrm{CCH}_{3}\right)_{4}(3-\mathrm{pyOH})_{2}\right]_{2}$ (2), $\left[\mathrm{Ru}\left(\mathrm{O}_{2} \mathrm{CC}_{6} \mathrm{H}_{5}\right)_{2}(3-\right.$ pyOH $\left.)_{2}\right]_{\mathrm{n}}(3)$ and $\left[\mathrm{Ru}\left(\mathrm{O}_{2}\left(\mathrm{CH}_{2}\right)_{4} \mathrm{CH}_{3}\right)_{2}(3-\mathrm{pyOH})_{2}\right]_{\mathrm{n}}$ (4) (where pyOH = hydroxypyridine) have been prepared by reacting 3-hydroxypyridine with ruthenium carboxylates. The complexes were characterized by IR spectra, elemental analyses, electronic absorption spectroscopy and single crystal X-ray crystallography. The X-ray diffraction study results revealed that the crystal structures of the complexes are triclinic, for 1; orthorhombic, for 2; and monoclinic, for both 3 and 4. Antimocrobial studies revealed that the four complexes are potential antimicrobial agents.
\end{abstract}

Keywords: 3-Hydroxypyridine, Ruthenium carboxylates, Distorted octahedral, Dimers, Antimicrobial

\section{Introduction}

Many metal ions carboxylates of both first and second roles of transition series have been complexed with different ligands (Bera et al, 2009, Anjani et al,2006, Naceur et al, 2010 and Vishunu et al,2006). Ligands with N-donor atom(s) have frequently been used to model the active site in metal proteins molecules with aim to obtain insight into the correlation between structures, the spectroscopic and magnetic behaviors (Pernark et al, 200, Sheela et al, 2010, Carissa et al, 2003). Researchers have made efforts to design new synthetic routes for preparation of transition metal carboxylates with additional N-donor ligands (Sheela et al 2010, Sweetina et al, 2005).

Ligands with nitrogen bond and functionality could lead to the formation of useful inorganic materials with interesting physical properties. Synthesis of $\left[\mathrm{Cu}\left(\mathrm{O}_{2} \mathrm{CCF}_{3}\right)_{2}(3-\mathrm{pyOH})_{2}\right](\mathrm{THF})_{2}$ in which two dimensional network linked by hydrogen bonds between the trifluoroacetate ligands and the (3-pyOH) has been reported recently (Hong-Ling et al, 2001). It was found that 3-pyOH ligands has two functions: capable of forming both metal-ligand and hydrogen bonds. This results in extended two-dimensional sheet structures also in $\left[\mathrm{Cu}\left(\mathrm{O}_{2}\left(\mathrm{CF}_{3}\right)_{2}(3-\mathrm{pyOH})_{2}\right] \mathrm{n}\right.$. $\left[\mathrm{Cu}(\mathrm{ox})(3-\mathrm{pyOH})_{2}\right] \mathrm{n}$ has been reported to have be an extended one-dimensional complex (Hong-Ling et al, 2001).

Despite such interesting exhibitions, only few coordination compounds of $\mathrm{M}^{\mathrm{n}+}$ carboxylates with 3-hydroxypyridine (3-pyOH) have been fully characterized so far.

Research to find platinum and iridium containing anti-cancer drugs is actively being pusued (Jens et al, 2010, 
Na-Xu et al, 2008, Antony et al, 1992, Ljerka et al, 2003, Antonio et al, 2001).

Tetrazine complexes of tin and zinc ions are known to have anti-fungicidal and anti tumor activities (Okabe $e t a l$, 2000, Motohashi et al, 2000). Some have been used in the treatments of fungi skin diseases, bladder and cervical tumors, ovarian and testicular cancers (Young- Jae et al, 2000, Violeta et al, 2010)

Unfortunately, their side effects are serious: cause of skin irritation, nausea and kidney damage (Anjani et al, 2006, Kovala et al, 1997 and Naceur et al, 2010). Therefore need for clinically active with fewer side-effect new compounds is being vigorously pursued.

Due to the increase number of immuno-compromised individuals, fungal infections have increase steadily in the last two decades, affecting millions of people worldwide (Vishunu et al, 2006). Opportunistic systematic mycoses are associated to high rates of deaths; and skin fungal infections, although not life threatening, debilitate patients' quality of life, with additional danger that can spread to other areas of the body and other individuals (Motohashi et $a l, 2000$, Jens et al, 2010). Although several drugs have been developed for the treatment of systemic an superficial mycoses, there are, in fact, a limited number of efficacious antifungal drugs. Many of the currently available drugs have undesirable side-effects or are very toxic, produce reoccurrence or lead to the development of resistance (Carissa et al, 2003, Okabe et al, 2000, Sweetina et al, 2005) As a consequence, there is a real need for a next generation of antifungal agents. Therefore need for clinically active with fewer side-effect new compounds is being vigorously pursued.

We present, in this work, synthesis, characterization and antibiocidal activities of ruthenium carboxylates complexed with 3-pyOH. It also includes our efforts to find new synthesis routes for preparation of transition metal carboxylates with additional N-donor ligands.

\section{Experimental}

\subsection{Physico-chemical measurements}

All chemicals used were analytical reagent grade purchased from Aldrich and used without further purification. Micro analytical data were obtained on a Perkin Elmer model 2400 elemental analyzer. IR spectra were obtained as $\mathrm{KBr}$ disks on a Perkin Elmer model $1600 \mathrm{FT}$-IR spectrophotometer, in the range of $400-4500 \mathrm{~cm}^{-1}$. Electronic spectra were recorded in $\mathrm{CH}_{2} \mathrm{Cl}_{2}$ and $\mathrm{MeOH}$ solutions with a Spectronic, Genesys 2, spectrophotometer. Single crystal data were collected at room temperature on a Bruker Smart CCD diffractometer equipped with graphite monochromated Mo K $\alpha$ radiation $(\lambda: 0.71073 \AA)$. Absorption corrections were performed using the multi scan method. SHELXL97 ${ }^{12}$ were used for the structure resolution. The magnetic susceptibility data were determined for the power samples over the temperature range $200-300 \mathrm{~K}$ by using a SQUID magnetometer (QUANTUM DESING MODEL MPMS-XL5 instrument). All susceptibility data were corrected for the diamagnetism of constituent atoms using Pascal's constant. EPR spectra were recorded on JEOL JES RE2X spectrometer using a rectangular cavity with a $50 \mathrm{KHz}$ field modulation. Bacterial and fungal strains: Staphylococcus aureus, Bacillus cereus, Pseudomonas aeruginosa, Salmonella enteritidis, Escherichia coli, Klebsiella pneumonia, Agaricus bisporus, Agrocyte arvalis and Actinocorallia herbida used in this study are property of the Department of Biological Sciences, Bowen University, Iwo, Nigeria.

The standardized disc agar diffusion method was followed to determine the activities of the synthesised compounds against the sensitive organisms (Bera et al, 2009). Staphylococcus aureus, Bacillus cereus and Pseudomonas aeruginosa as Gram positive bacteria, Salmonella enteritidis, Escherichia coli and Klebsiella pneumonia as Gram negative bacteria and three species of fungi namely, Agaricus bisporus, Agrocyte arvalis and Actinocorallia herbida. The antibiotic, chloramphenicol was used as reference in the case of Gram negative bacteria, while cephalothin as used in the case of Gram positive bacteria and cycloheximide was used as antifungal reference. The compounds were dissolved in DMF which has no inhibition activity to get concentration of $1.50 \mathrm{mg}$ $\mathrm{mL}^{-1}$. The test was performed on medium potato dextrose agars which contain infusion of $200 \mathrm{~g}$ potatoes, $6 \mathrm{~g}$ dextrose and $15 \mathrm{~g}$ agar. Uniform size filter paper disks were impregnated with equal volume $(10 \mu \mathrm{L})$ from specific concentration of dissolved tested compounds and carefully placed on inoculated agar surface. These were incubated for $48 \mathrm{~h}$ at $26^{\circ} \mathrm{C}$ in the case of bacteria and for $48 \mathrm{~h}$ at $24^{\circ} \mathrm{C}$ in the case of fungi.

\subsection{Preparation of complexes}

\subsection{1 $\left[\mathrm{Ru}\left(\mathrm{O}_{2} \mathrm{CCH}_{3}\right)_{2}(3-\mathrm{pyOH})_{2}\right](\mathbf{1})$}

$20 \mathrm{~mL}$ of $0.26 \mathrm{~g}$ of well filtered solution of $\left[\mathrm{Ru}\left(\mathrm{O}_{2} \mathrm{C}_{(}\left(\mathrm{CH}_{2}\right)_{2} \mathrm{CH}_{3}\right)_{4}\left(\mathrm{H}_{2} \mathrm{O}\right)_{2}\right]$, prepared in absolute ethanol was mixed with $13.00 \mathrm{~mL}$ of $2.26 \mathrm{~g}(0.22 \mathrm{mmol})$ of 3-hydroxypyridine in $6.5 \mathrm{~mL}$ absolute ethanol, stirred thoroughly, then heated gently on a hotplate to a temperature of $50^{\circ} \mathrm{C}$ and kept at this temperature for $5 \mathrm{hrs}$. 
The reaction mixed was then allowed to cool to room temperature and further cooled to $5^{\circ} \mathrm{C}$ in ice bath. The violet crystals precipitate was filtered off. Re-crystalized twice in n-heptane and then dried in desicator over $\mathrm{KOH}$ for 3 days.

2.2.2 $\left[\mathrm{Ru}_{2}\left(\mathrm{O}_{2} \mathrm{CCH}_{3}\right)_{4}(3-\text { py } \mathrm{OH})_{2}\right]_{2}(2)$

$1.20 \mathrm{~g}$ ( $3 \mathrm{mmol})$ of $35 \mathrm{~mL}$ of absolute ethanolic solution of $\mathrm{Ru}_{2}\left(\mathrm{O}_{2} \mathrm{CCH}_{3}\right)_{4}$ were added to $0.56 \mathrm{~g}(5 \mathrm{mmol})$ of 3-py $\mathrm{OH})$ in $10 \mathrm{~mL}$ of absolute ethanol and then heated gently on a hotplate to a temperature of $55^{\circ} \mathrm{C}$. The temperature was maintained for 17 hours. Allowed to cool to room temperature and then further cooled in a water bath to $+8^{\circ} \mathrm{C}$. The crystals formed were filtered off and re-crystalised twice in n-heptane.

2.2.3 $\left[\mathrm{Ru}\left(\mathrm{O}_{2} \mathrm{CC}_{6} \mathrm{H}_{5}\right)_{2}(3-\mathrm{py} \mathrm{OH})_{2}\right]_{\mathrm{n}}$ (3)

$0.33 \mathrm{~g}(0.5 \mathrm{mmol})$ of $\mathrm{Ru}\left(\mathrm{O}_{2} \mathrm{CC}_{6} \mathrm{H}_{5}\right)$ dissolved in $30 \mathrm{~mL}$ of hot $\mathrm{CH}_{3} \mathrm{CN}$ was mixed with $0.58 \mathrm{~g}$

( $7 \mathrm{mmol}$ ) of 3-pyOH dissolved in $15 \mathrm{~mL}$ of absolute ethanol. The mixture was thoroughly stirred and then placed on a hotplate with magnetic stirrer, heated for 2 hours. The violet plate-like crystals precipitated was filtered off while still hot, and then re-crystallised from n-heptane. The product was washed with very small portions of cold methanol and dried over $\mathrm{KOH}$.

2.2.4 $\left[\mathrm{Ru}\left(\mathrm{O}_{2} \mathrm{C}\left(\mathrm{CH}_{2}\right)_{4} \mathrm{CH}_{3}\right)_{2}(3-\mathrm{pyOH})_{2}\right]_{\mathrm{n}}$ (4)

Hot $5.5 \mathrm{~mL}$ of $0.42 \mathrm{~g}(0.6 \mathrm{mmol})$ of $\mathrm{Ru}\left(\mathrm{O}_{2} \mathrm{C}\left(\mathrm{CH}_{2}\right)_{4} \mathrm{CH}_{3}\right)_{2}$ dissolved in a hot mixture of $10 \mathrm{~mL} \mathrm{of} \mathrm{CH}_{3} \mathrm{OH}$ and $\mathrm{CH}_{3} \mathrm{CN}(1: 1, \mathrm{v} / \mathrm{v})$ were filtered into a solution of $0.22 \mathrm{~g}(1.1 \mathrm{mmol}$.) of 3-py $\mathrm{OH}$ in $4.0 \mathrm{~mL}$ of the same mixture of solvents., stirred thoroughly then placed on a hot plate with magnetic stirrer, heated and refluxed for $2 \mathrm{hrs}$. The resulting solution was allowed to cool to room temperature and stored in a refrigerator for 2 weeks.

The blue-violet crystals formed were then filtered off. The crystals were purified by recrystallisation with n-heptane. Then dried in desiccator over $\mathrm{KOH}$ for 5 days.

\section{Results and Discussion}

All reactions of 3-pyOH with metals ions are strongly dependent on the $\mathrm{pH}$ of the solution because it is an organic ampholyte which is acidic medium can attract easily a proton to its pyridine nitrogen atom, while in basic medium its $\mathrm{O}-$ hydrogen group can easily dissociate. The equation for the preparation of compound 1 is written below:

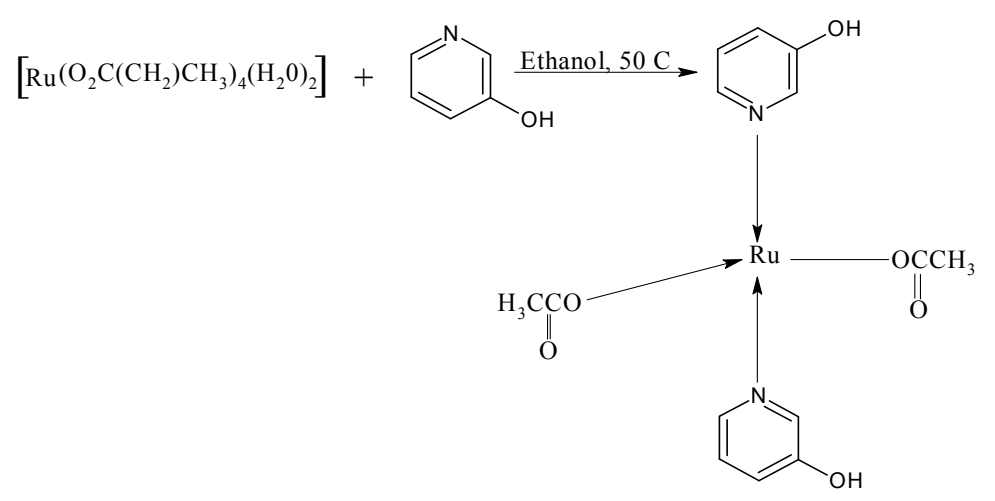

Table 1 shows the percentage yields, colour, melting points and other determined properties of the complexes prepared. The micro-elemental analyses, presented in Table 1 agree with the X-ray results.

Significant frequencies were selected by comparing the IR spectra of the free ligands and its metal complexes.

A strong band typical of $\mathrm{C}=\mathrm{C}$ stretching frequency, $v$, are found in all the complexes in the region of 1632-1638 $\mathrm{cm}^{-1}$ and $1622 \mathrm{~cm}^{-1}$ in the free ligand. The observed shifts on the $v(C=N)$ stretch regions after complexation indicate that they have been affected upon co-ordination to metal ion which also indicate the formation of $\mathrm{Ru}-\mathrm{N}$ bonds whose IR stretching frequencies are all in the range of $602-608 \mathrm{~cm}^{-1}$. The $v(\mathrm{C}=\mathrm{N})$ bond is shifts to a lower region in the complexes. This indicates that $\mathrm{N}$ must be involved in the coordination in the complexes. Additionally, the characteristic carbonyl stretching frequency observed in the IR spectra of the free ligand is shifted to around 1680 in all the complexes. The occurrence of new bands in the $738-748 \mathrm{~cm}^{-1}$ region in the IR spectra of the metal complexes confirm the presence of Ru-N. The IR spectrum of the ligand shows broad bands at $3446-3553 \mathrm{~cm}^{-1}$, 
which are attributed to the phenolic $\mathrm{OH}$ group. These bands are not found in all the complexes. The absence of the $\mathrm{O}-\mathrm{H}$ stretching bonding vibrations from the spectra of the complexes indicates deprotonation of the $\mathrm{O}-\mathrm{H}$ group.

The $v(\mathrm{C}=\mathrm{N})$ stretching band in the free ligand is observed at $1690 \mathrm{~cm}^{-1}$. This band is shifted to lower $1678-1684$ $\mathrm{cm}^{-1}$ upon complexation suggesting coordination via the $\mathrm{N}$ atom of the pyridyl group. Other details are shown in Table 2 .

The electronic absorption spectrum of each of the complexes recorded in EtOH and DMF solutions shows four bands at $211-234,244-258,262-294$ and $368-415 \mathrm{~nm}$ which were attributed to the $\pi \rightarrow \pi^{*}$ and $\mathrm{n} \rightarrow \pi^{*}$ transitions. The uv spectra of the complexes also show other bands at $474-483,510-522,532-539,711-719$, assignable to $4 \mathrm{~T}_{1 \mathrm{~g}} \rightarrow 6 \mathrm{~A}_{1 \mathrm{~g}}, 4 \mathrm{~T}_{2 \mathrm{~g}}(\mathrm{G}) \rightarrow 6 \mathrm{~A}_{1 \mathrm{~g}}, 4 \mathrm{~T}_{1 \mathrm{~g}}(\mathrm{D}) \rightarrow 6 \mathrm{~A}_{1 \mathrm{~g}}$ and $5 \mathrm{~T}_{2 \mathrm{~g}} \rightarrow 5 \mathrm{E}_{\mathrm{g}}$ transitions, respectively, which lie in the same range as reported for octahedrally coordinated $\mathrm{Ru}$ (II) ion. The uv spectra revealed a band of medium intensity at $528-537 \mathrm{~nm}$ which is assigned to the transition $4 \mathrm{~T}_{1 \mathrm{~g}}(\mathrm{~F}) \rightarrow 4 \mathrm{~T}_{1 \mathrm{~g}}(\mathrm{P}) \mathrm{v}_{3}$. The band $320-329 \mathrm{~nm}$ is assigned to the charge transfer transition (L-MCT).

The magnetic susceptibility values of the complexes which are all in the range $5.2-5.7 \mathrm{~B}$. M. point toward that they are paramagnetic and also evidence of high spin octahedral structures. The low values of the molar conductance data listed in Table 1 indicate that the complexes are non-electrolytes.

The ORTEP drawings of complexes $\mathbf{1}$ - 4 molecules are presented in Figures 1 to 4 . The bond lengths and angles of complexes are presented in Table 5. Complexes $\mathbf{1}$ and $\mathbf{2}$ have similar structures at $150 \mathrm{~K}$ and room temperature (about $298 \mathrm{~K}$ ). The unit cells are smaller at room temperature, as expected. There is contraction of contact distances which are less affected by changes in the geometrical parameters of the complex molecules. The asymmetric unit of 1 consists of two half-units of $\left[\mathrm{Ru}\left(\mathrm{O}_{2} \mathrm{C}\left(\mathrm{CH}_{2}\right)_{2} \mathrm{CH}_{3}\right)_{2}(3-\mathrm{pyOH})_{2}\right] . \mathrm{Ru}^{2+}$ ion lies on inversion centre and is coordinated by two 3-pyOH ligands, trans coordinated through $\mathrm{N}$ atom and two a distances are 2.566

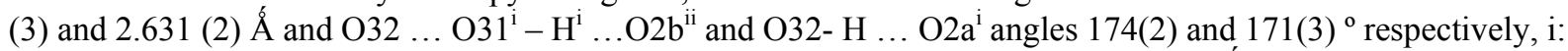
$-\mathrm{x},-\mathrm{y}+1,-\mathrm{z}+1$; ii: $-\mathrm{x},-\mathrm{y},-\mathrm{z}$. The $\mathrm{Ru}$...Ru contact distance within the chain is 5.436(4) $\AA$. The crystal packaging is also stabilizes by $\pi \ldots \pi$ and $\pi \ldots \sigma$ interactions among stacked heteroaromatic rings. Distance among ring centroids is 3. 686 (1) $\AA$. Dihedral between planes of these rings is $0^{\circ}$ and the angle between centroid vector and normal to ring plane is $24.9^{\circ}$. The conformation of complex molecules of $\mathbf{2}$ is of a paddle-wheel type. The molecules are centrosymmetric dimmers with four syn-syn bridging acetonato and two apical 3-pyOH ligands coordinated through $\mathrm{N}$ atoms. The coordination polyhedron of $\mathrm{Ru}$ is slightly distorted square pyramid. The apical Ru-N distance 2.146(3) $\AA$ is is significantly longer thanRu-O distances.

The $\mathrm{Ru}$... Ru separation within a dimer is 2.646 (4) $\AA$. Hydroxyl group is uncoordinated.It forms intermolecular hydrogen bond with $\mathrm{O} 21$ atom of symmetry related acetonato ligand linking the dimeric complex molecule in a two dimensional layer structure perpendicular to $c$ edge. Compounds $\mathbf{3}$ annd $\mathbf{4}$ contain 3-pyOH ligand and besides also benzonato of heptanato ligand which is larger in comparison with the aceonato ligand in $\mathbf{1}$ and $\mathbf{2}$. This is probably the reason that they have similar structures which differs completely from that of $\mathbf{1}$ or $\mathbf{2}$. In both structures, $\mathrm{N}$ and hydroxyl $\mathrm{O}$ atom form coordinated bond, resulting in a two-dimensional covalently bonded extended structure analogous to the trifluoroacetonato coordination compounds, with the same linkage pattern. ${ }^{15}$ Hydroxyl $\mathrm{O}$ atom in the two complexes forms additionally an intramolecular hydrogen bond with uncoordinated $\mathrm{O}$ atom of carboxylato ligand which has the consequence that also the coordination sphere is very similar. In the two cases, there is a distorted octahedral arrangement of bonded ligands. Detailed are contained in Tables 3 - 5. Crystallographic data (excluding structure factors) for the structures in this paper have been deposited with the Cambridge Crystallographic Data Centre as supplementary publication (CCDC no. 7217563).

Antimicrobial activities of these complexes at different concentrations were tested on Staphylococcus aureus, Bacillus cereus, Pseudomonas aeruginosa, Salmonella enteritidis, Escherichia coli, Klebsiella pneumonia, Agaricus bisporus, Agrocyte arvalis and Actinocorallia herbida. After incubation for $48 \mathrm{~h}$ at $26^{\circ} \mathrm{C}$, in the case of bacteria and for $48 \mathrm{~h}$ at $24^{\circ} \mathrm{C}$, in the case of fungi, inhibition of the organisms was measured and used to calculate mean of inhibition zones. Activity index of all the synthesized compounds was also calculated against the corresponding standard drug (Table 6). The products showed various activities against all species of microorganisms, which suggest the variations in the structures affect on the growth of the microorganisms. Complex $\mathbf{2}$ is the most effective against gram-positive $S$. aureus, B. cereus, and P. aerugiosa, while complex $\mathbf{4}$ is the most effective against gram-negative $E$. coli, and $K$. pneumonia. Thus, we can conclude from these results: The prepared compounds have been fully characterised and they showed a moderate to high antimicrobial activity towards the species of bacteria and fungi. Therefore, these compounds may be considered promising for the development of new antimicrobial agents. However, there is still need for us to investigate their toxicity and selectivity to animals and human beings. 


\section{References}

Anjani, K., Tiwari, A. K., Vinay, K. S. (2006). Synthesis and Pharmacological Study of Novel Pyrido-quinazolone Analogues as Antifungal, Antibacterial and Anticancer Agents. Bioorg. and Med. Chem. Let., 16 (17), 4581-4585.

Anthony, E. Liberta, Douglas X. West. (1992). Antifungal and Antitumor Activity of Heterocyclic thiosemicarbazones And Their Metal Complexes: Current Status. J. Chem. Res., 5, 121-126.

Antonio, Carta, Paolo, Sanna, Gheradini, Laura, Donatella, Usai, Zanetti, Stefania. (2001). Novel Functionalized Pyrido[2,3-g]quinoxalinones as Antibacterial, Antifungal and Anti cancer Agents. 11 Farmaco., 56(12), 933-938.

Bera, P. (2009). Synthesis And Spectroscopic Characterization on New Iron(III) Complexes of S-Alky/Aryl dithiocarbazates of 5-melthy-3-formlypyrazolyl-thiosemicarbazones. Rus. Jour. of Coord. Chem., 35(7), 336-339.

Carissa, M. Cawich, Ibrahim, Amitha, Karen, L. Link, Allan, Bumgartner, Mata, D. Patro, Surendra, N. Mahapatra. (2003). Synthesis of a Pyridinium Bis[citrate(2-)]oxochromate(V) Complex and Its LigandExchange Reactions. Inorg. Chem., 42(20), 6458-6468.

Hong-Ling, Gao, Long Yi, Zhao, Xiao-Qing, Zhao, Perg, Chang, Dai-Zhang, Liao, Shi-Ping, Yan. (2006). Synthesis and Characterization of Metal-Organic Frameworks Based on 4-Hydroxypyridine-2,6-dicarboxylic Acid and Pyridine-2,6- dicarboxylic Acid Ligands. Inorg. Chem., 45 (15), 5980-5987.

Jens, Langer, Dark, Walther, Astrid, Malassa, Matthias, Westerhausen, Helmar, Gorls. (2009). Nickelacylic Caboxylates With Pyridine-Based Ligand Sets - From Mononuclear Complexes to Supramolecular Architectures by Hydrogen Bonding. Euro. J. of Inorg. Chem., 2010 (2), 275-281.

Kovala-Demertzi, Dimitra, Asimina, Domopoulou, Douglas, West. (1997). Palladium(II) Complexes of 2-Acetylpyridine N(4)- propyl,N(4)-dipropyl And 3-hexamethylene iminylthiosemicarbazones With Potentially Interesting Biological Activity. Synthesis, Spectral Properties, Antifungal and Invitro Antitumor Activity. Polyhedron, 16(20), 3625-3633.

Ljerka, Tusek-Bozic, Frausin, Fabiana, Furlani, Ariela. (2003). Synthesis, Characterization And Antitumor Activity of Platinum (II) Complexes With Diethyl And Monoethyl 2-quinolymethylphosphonates. J. of Inorg. Biochem., 95 (4), 259-269.

Motohashi, N., Kawase, M., Saito, S., Sakagami, H. (2000). Antitumor Potential And Possible Targets of Phenothiazine Related Componds. Polyhedron, 1 (3), 237-246.

$\mathrm{Na}, \mathrm{Xu}$, Wei, Shi, Dai-Zheng, Liao, Shin-Ping, Yan, Peng, Cheng. (2008). Template of Lanthanides (Pr, Nd, Gd) Coordination Polymers With 2-Hydroxynicotinic Acid Exhibiting Ferro-/Antiferromagnetic Interactions. Inorg. Chem., 47 (19), 8748-8756.

Naceur, Hamdi, Fenten, Bouabdallah, Antonio, Romerosa, Benhasan, Rachel. (2010). Expedious Synthesis of $\alpha$, $\beta$-unsaturared Coumarin Derivatives Using Boran Chelates: A Novel Class of Potential Antibacterial and Antioxidant Agents. Comptes Rendus Chimie, 45 (3) 231-238.

Okabe, N., Oya, N. (2000). Crystal Structure of Bis( $\mu$-pyridine-2,6-carboxylato- O, N,O: O)bis [triaguamanganese(II)-pyridine-2,6-dicarboxylic Acid]. Acta Cryst., C 56 part 12, 1416- 1417.

Pernak, J., Kalewska, J., Ksycinska, H., Cybulski, J. (2001). Synthesis and Antimicrobial Activities of Some Pyridinium Salts With Alkoxymethyl Hydrophobic Group. Eur. J. Med. Chem., 36 (11-12), 899-907.

Sheela, C. D., Anitha, C., Thamary, P., Kodimunthri, D. (2010). Synthesis, Characterization and Antimicrobial Studies of Metal Complexes of Schiff Base Derived From [ 4-Amino-N- guanylleenzene Sulfonamide] and Salicylaldehyde. J. of Coord. Chem., 63(5), 884- 893.

Swetiana, Gez, Robert, Lexenhofer, Aviva, Levina, Codd, Rachel, Peter, L. (2005). Chromium(V) Complexes of Hydroxami Acids; Formation, Structure and Reactivities. Inorg. Chem., 44(8), 2934-2943.

Violeta S. J., Giorgio, P. and Sonja, N. K. (2010). Synthesis, Structural Studies and Biological Activity of Dioxovanadium (V) Complex with Pyridoxal Semi carbazone. Acta Chim. Slov., 57, 363 - 369.

Vishunu, K. Tandon, Dharmendra, B., Yadav, B. (2006). Design, Synthesis and Biological Evaluation of 1,2,3-Trisubstituted-1,4.dihydro[g]quinoxaline-5,10-diones and Related Compounds as Antifungal and Antibacterial Agents. Bioorg. and Med. Chem. Let., 14(17), 6120-6126. 
Youg-Jae,You, Yong Kim, Gyu-Yong, Song, Byung-Zun. (2000). (E)-6-(1-Alkyloxyiminoalkyl)-5,8-dimethoxy-1,4-napthoquinone: Synthesis, Zytotoxic Activity and Antitumor Activity. Bioorg. And Med. Chem. Let., 10 (20), 2301- 2303.

Table 1. Physical properties and elemental analysis of the complexes

\begin{tabular}{|c|c|c|c|c|c|c|c|c|}
\hline \multirow[b]{2}{*}{$\begin{array}{l}\text { Empirical formula } \\
\text { (formula weight) }\end{array}$} & \multirow[b]{2}{*}{ Colour } & \multirow[b]{2}{*}{$\begin{array}{l}\text { Yield } \\
(\%)\end{array}$} & \multicolumn{5}{|c|}{ Analysis \% found ( calculated ) } & \multirow[b]{2}{*}{$\begin{array}{l}\lambda \mathrm{m}\left(\Omega^{-1}\right) \\
\left.\mathrm{cm}^{2} \mathrm{Mol}^{-1}\right)\end{array}$} \\
\hline & & & M. $\operatorname{Pt}\left({ }^{\circ} \mathrm{C}\right)$ & $\mathrm{N}$ & $\mathrm{H}$ & \multicolumn{2}{|c|}{$\begin{array}{l}\mu \text { eff } \\
\text { (B.M.) }\end{array}$} & \\
\hline $\begin{array}{l}{\left[\mathrm{Ru}\left(\mathrm{O}_{2} \mathrm{CCH}_{3}\right)_{2}(3-\mathrm{py}-\mathrm{OH})_{2}\right]} \\
(377.15)\end{array}$ & Green & 38.43 & $234-235$ & $7.12(7.05)$ & $43.40(42.38)$ & $2.84(2.78)$ & 5.6 & 8.46 \\
\hline $\begin{array}{l}{\left[\mathrm{Ru}_{2}\left(\mathrm{O}_{2} \mathrm{CCH}_{3}\right)_{2}(3-\mathrm{py}-\mathrm{OH})_{2}\right]_{2}} \\
(1128.31)\end{array}$ & Green & 43.05 & $287-289$ & $6.25(6.27)$ & $36.86(36.88)$ & $2.36(2.37)$ & 5.2 & 9.22 \\
\hline $\begin{array}{l}{\left[\mathrm{Ru}\left(\mathrm{O}_{2} \mathrm{CC}_{6} \mathrm{H}_{5}\right)_{2}(3-\mathrm{pyOH})_{2}\right] \mathrm{n}} \\
(477.13) \mathrm{n}\end{array}$ & Grenish-yellow & 32.22 & $373-375$ & $6.74(6.72)$ & $39.56(39.58)$ & $2.74(2.73)$ & 5.7 & 7.78 \\
\hline $\begin{array}{l}{\left[\mathrm{Ru}\left(\mathrm{O}_{2} \mathrm{C}\left(\mathrm{CH}_{2}\right)_{4} \mathrm{CH}_{3}\right)_{2}\right)(3-\mathrm{pyOH}} \\
(489.12) \mathrm{n}\end{array}$ & H) $)_{2}$ ] Yellowish & 25.72 & $343-345$ & $5.38(5.37)$ & $43.21(43.23)$ & $2.41(2.39)$ & 5.3 & 6.37 \\
\hline
\end{tabular}

Table 2. Selected infrared band $\left(\mathrm{cm}^{-1}\right)$ of synthesized typical monomeric and polymeric ruthenium compounds

\begin{tabular}{|c|c|c|c|c|c|c|c|c|c|}
\hline \multirow{2}{*}{$\begin{array}{l}\text { Compd } \\
\text { 3pyOH }\end{array}$} & \multicolumn{2}{|c|}{$v(\mathrm{C}-\mathrm{H}) v\left(\mathrm{C}-\mathrm{H}_{2}\right.$, asy. $)$} & \multirow{2}{*}{$\begin{array}{c}v\left(\mathrm{CH}_{2, \mathrm{sym} .}\right) \\
2902, \mathrm{~s}\end{array}$} & \multirow{2}{*}{$\begin{array}{c}\text { v C =C) ar, sym) } \\
1622, \mathrm{~m}\end{array}$} & \multirow{2}{*}{$\begin{array}{c}v(\mathrm{C}-\mathrm{C}, \text { ar, sym. }) \\
1472, \mathrm{~s}\end{array}$} & \multicolumn{2}{|c|}{$v(\mathrm{C}=\mathrm{O}) v(\mathrm{Ru}-\mathrm{O})$} & \multirow{2}{*}{$\begin{array}{c}v(\mathrm{Ru}-\mathrm{N}) \\
-\end{array}$} & \multirow{2}{*}{$\begin{array}{c}v(\mathrm{C}=\mathrm{N}) \\
1690, \mathrm{~s}\end{array}$} \\
\hline & H $3102, \mathrm{~m}$ & $2990, \mathrm{~s}$ & & & & $1578, \mathrm{~m}$ & - & & \\
\hline 1 & $2955, \mathrm{~s}$ & $2920, \mathrm{~s}$ & $2852, \mathrm{~m}$ & $1606, \mathrm{~m}, 1514, \mathrm{~s}$ & $1433, \mathrm{~m}$ & $1560, \mathrm{~m}$ & $795, \mathrm{~s}$ & $746, \mathrm{~m}$ & $1684, \mathrm{~m}$ \\
\hline 2 & 2962, s, 2913, & s 2924, m & $2856, \mathrm{~s}$ & $1615, \mathrm{~m} \mathrm{1524, \textrm {s }}$ & $1428, \mathrm{~s}$ & $1564, \mathrm{~s}$ & $802, \mathrm{~m}$ & $730, \mathrm{~s}$ & $1680, \mathrm{~s}$ \\
\hline 3 & $2954, \mathrm{~m}$ & $2919, \mathrm{~s}$ & $2858, \mathrm{~s}$ & $1600, \mathrm{~s} 1522, \mathrm{~s}$ & $1438, \mathrm{~s}$ & $1558, \mathrm{~m}$ & $796, \mathrm{~s}$ & $738, \mathrm{~s}$ & $1678, \mathrm{~m}$ \\
\hline 4 & $2955, \mathrm{~m}$ & $2922, \mathrm{~s}$ & $2865, \mathrm{~m}$ & $1608, \mathrm{~m} \mathrm{1519, \textrm {s }}$ & $1440, \mathrm{~m}$ & $1557, \mathrm{~s}$ & $796, \mathrm{~m}$ & $736, \mathrm{~s}$ & $1676, \mathrm{~s}$ \\
\hline
\end{tabular}


Table 3. Crystallographic data and structure refinements details of the complexes

\begin{tabular}{|c|c|c|c|c|}
\hline & Complex 1 & Complex 2 & Complex 3 & Complex 4 \\
\hline Empirical Formula & $\mathrm{RuC}_{9} \mathrm{NH}_{9} \mathrm{O}_{9}$ & $\mathrm{Ru}_{2} \mathrm{C}_{18} \mathrm{~N}_{2} \mathrm{H}_{22} \mathrm{O}_{18}$ & {$\left[\mathrm{RuC}_{22} \mathrm{~N}_{2} \mathrm{H}_{20} \mathrm{O}_{6}\right]_{\mathrm{n}}$} & $\left.\mathrm{RuC}_{22} \mathrm{~N}_{2} \mathrm{H}_{32} \mathrm{O}_{6}\right]_{\mathrm{n}}$ \\
\hline Formula weight & 377.07 & 1128.31 & {$[477.13]_{\mathrm{n}}$} & {$[489.12]_{\mathrm{n}}$} \\
\hline Temperature (K) & $120(1)$ & $120(1)$ & $120(1)$ & $120(1)$ \\
\hline Wavelength $(\AA \hat{)})$ & 0.73423 & 0.63828 & 0.74827 & 0.70428 \\
\hline Crystal system & Triclinic & orthorhombic & monoclinic & monoclinic \\
\hline Space group & $P-1$ & $\mathrm{Pca}_{1}$ & $P 21 / n$ & $P 21 / n$ \\
\hline \multicolumn{5}{|l|}{ Unit cell Dimensions } \\
\hline$a(\AA)$ & $8.862(2)$ & $8.474(2)$ & $9.765(2)$ & $10.684(2)$ \\
\hline$b(\AA))$ & $9.9983(2)$ & $14.9983(2)$ & $9.9983(2)$ & $9.9983(2)$ \\
\hline$c(\AA \AA)$ & $10.0634(2)$ & $23.040(1)$ & $10.8360(2)$ & $10.0481(2)$ \\
\hline$\alpha$ & $99.264(1)$ & $90.00(1)$ & $90.00(1)$ & $90.00(1)$ \\
\hline$\beta$ & $92.245(1)$ & $90.00(1)$ & $90.00(1)$ & $90.00(1)$ \\
\hline$\gamma$ & $114.623(4)$ & $90.00(1)$ & $104.682(1)$ & $100.415(1)$ \\
\hline Vol., $\left(\AA^{3}\right)$ & $793.35(2)$ & $853.35(2)$ & $883.35(2)$ & $863.35(2)$ \\
\hline Z & 2 & 8 & 2 & 2 \\
\hline$\rho($ calculated $) \mathrm{gcm}^{-3}$ & 1.256 & 1.756 & 1.476 & 1.486 \\
\hline Absorption coefficient $\left(\mathrm{mm}^{-1}\right)$ & ) 1.053 & 1.067 & 1.305 & 1.285 \\
\hline $\mathrm{F}(000)$ & 348 & 359 & 360 & 339 \\
\hline Crystal size (mm) & $.5 \times 0.1 \times 0.5$ & $0.5 \times 0.1 \times 0.5$ & $0.5 \times 0.1 \times 0.5$ & $0.5 \times 0.1 \times 0.5$ \\
\hline Reflection collected / unique & $18636 / 10831$ & 19488/ 13126 & $17495 / 18321$ & $19432 / 16932$ \\
\hline Refinement method & $\mathrm{F}^{2}$ & $\mathrm{~F}^{2}$ & $\mathrm{~F}^{2}$ & $\mathrm{~F}^{2}$ \\
\hline Data/restraints/parameters & $1,143 / 7 / 138$ & $1,237 / 6 / 163$ & $1,156 / 7 / 172$ & $1,145 / 7 / 149$ \\
\hline Goodness-of-fit on $\mathrm{F}^{2}$ & 1.065 & 1.170 & 1.085 & 1.028 \\
\hline
\end{tabular}


Table 4. Atomic coordinates $\left(\mathrm{x} 10^{4}\right)$ and equivalent isotropic displacement parameters $\left(\AA^{2} \times 10^{3}\right)^{p}$ for $\quad \mathbf{1}$, $\left[\mathrm{Ru}\left(\mathrm{O}_{2} \mathrm{CCH}_{3}\right)_{2}(3-\mathrm{pyOH})_{2}\right]$

\begin{tabular}{ccccc} 
Atom & $\mathrm{X}$ & $\mathrm{Y}$ & $\mathrm{Z}$ & $\mathrm{U}(\mathrm{eq})^{y}$ \\
$\mathrm{Ru}$ & $7746(1)$ & $5667(1)$ & $5319(1)$ & $18(1)$ \\
$\mathrm{O}(1 \mathrm{a})$ & $6458(2)$ & $4721(1)$ & $5690(1)$ & $17(1)$ \\
$\mathrm{O}(1 \mathrm{~b})$ & $5532(2)$ & $3489(1)$ & $5563(1)$ & $17(1)$ \\
$\mathrm{O}(2 \mathrm{a})$ & $1423(2)$ & $2427(2)$ & $7453(1)$ & $24(1)$ \\
$\mathrm{O}\left(2 \mathrm{a}^{\prime}\right)$ & $1216(3)$ & $1211(2)$ & $7532(1)$ & $22(1)$ \\
$\mathrm{O}(2 \mathrm{~b})$ & $6542(3)$ & $7217(2)$ & $7564(1)$ & $23(1)$ \\
$\mathrm{C}(1 \mathrm{~b})$ & $6747(3)$ & $3876(2)$ & $5991(2)$ & $16(1)$ \\
$\mathrm{C}(2 \mathrm{a})$ & $7668(4)$ & $3164(2)$ & $6512(2)$ & $16(1)$ \\
$\mathrm{C}(21)$ & $9444(4)$ & $3309(2)$ & $6718(2)$ & $17(1)$ \\
$\mathrm{C}(22)$ & $10275(4)$ & $2578(2)$ & $7140(2)$ & $19(1)$ \\
$\mathrm{C}(31)$ & $9430(4)$ & $1718(2)$ & $7369(2)$ & $20(1)$ \\
$\mathrm{C}(52)$ & $7528(4)$ & $3309(2)$ & $6718(2)$ & $17(1)$ \\
$\mathrm{C}(62)$ & $6707(4)$ & $2308(2)$ & $6751(2)$ & $19(1)$ \\
O (1a) & $5268(2)$ & $6342(1)$ & $6176(1)$ & $17(1)$ \\
O (2a) & $2932(2)$ & $5191(2)$ & $6036(1)$ & $16(1)$ \\
O (2a') & $4863(2)$ & $8461(2)$ & $9142(1)$ & $23(1)$ \\
O (2b) & $4212(1)$ & $7123(2)$ & $7821(1)$ & $15(1)$ \\
\hline
\end{tabular}

${ }^{p} \mathrm{U}(\mathrm{eq})$ is define as one third of the trace of the orthogonalized $\mathrm{U} i j$ tensor, $\mathrm{X}, \mathrm{Y}$, and $\mathrm{Z}$ are fractional atomic coordinates

Table 5. ${ }^{k}$ Selected bond lengths ( $\AA$ ) and bond angles $\left({ }^{\circ}\right)$ for complexes 1- 4

\begin{tabular}{|c|c|c|c|}
\hline \multicolumn{4}{|l|}{ Complex 1} \\
\hline $\mathrm{Ru} 1-\mathrm{O}(1 \mathrm{a})$ & $1.527(16)$ & $\mathrm{O}(1 \mathrm{a})-\mathrm{Ru} 1-\mathrm{N}(11)$ & $89.96(5)$ \\
\hline $\mathrm{Ru} 2$ - O(1b) & $1.863(5)$ & $O(1 a)-R u 1-O(2 a)$ & $56.374(3)$ \\
\hline Ru1- N(11) & $2.0333(1)$ & $\mathrm{O}(1 \mathrm{~b})-\mathrm{Ru} 2-\mathrm{N}(12)$ & $88.98(6)$ \\
\hline Ru2- N(12) & $1.968(3)$ & $\mathrm{O}(1 \mathrm{~b})-\mathrm{Ru} 2-\mathrm{O} 2 \mathrm{~b}(11)$ & $90.23(3)$ \\
\hline Ru1- O(2a) & $2.613(3)$ & $\mathrm{O}(2 \mathrm{a})-\mathrm{Ru} 1-\mathrm{O} 2 \mathrm{~b}$ & $90.15(3)$ \\
\hline $\mathrm{Ru} 2-\mathrm{O} 2 \mathrm{~b}$ & $2.5962(2)$ & $\mathrm{O}(2 \mathrm{~b})-\mathrm{Ru}-\mathrm{N} 12$ & $87.03(3)$ \\
\hline \multicolumn{4}{|l|}{ Complex 2} \\
\hline Ru-O11 & $1.874(2)$ & $\mathrm{O} 11-\mathrm{Ru}-\mathrm{O} 21^{\mathrm{i}}$ & $168.47(4)$ \\
\hline $\mathrm{Ru}-\mathrm{O} 12$ & $1.968(2)$ & $\mathrm{O} 11-\mathrm{Ru}-\mathrm{O} 22^{\mathrm{i}}$ & $89.45(5)$ \\
\hline $\mathrm{Ru}-\mathrm{O} 21^{\mathrm{i}}$ & $1.996(4)$ & O11-Ru-O12 & $89.66(6)$ \\
\hline $\mathrm{Ru}-\mathrm{O} 22$ & $1.978(2)$ & O-11-Ru-N1 & $96.96(6)$ \\
\hline $\mathrm{Ru}-\mathrm{Ni}$ & $2.231(3)$ & $\mathrm{O} 21^{\mathrm{i}}-\mathrm{Ru}-\mathrm{O} 12$ & $90.58(3)$ \\
\hline O12-Ru-N1 & $96.47(5)$ & $\mathrm{O} 21^{\mathrm{i}}-\mathrm{Ru}-22^{\mathrm{i}}$ & $88.13(6)$ \\
\hline \multicolumn{4}{|l|}{ Complex $\mathbf{3}$} \\
\hline Ru-N11 & $2.130(3)$ & $\mathrm{N} 11-\mathrm{Ru}-\mathrm{O} 31^{\mathrm{ii}}$ & $84.39(6)$ \\
\hline $\mathrm{Ru}-\mathrm{N} 12$ & $2.014(2)$ & N11-Ru-N12 & $177.87(6)$ \\
\hline $\mathrm{Ru}-\mathrm{O} 13$ & $1.893(2)$ & $\mathrm{N} 11-\mathrm{Ru}-\mathrm{O} 32^{\mathrm{iii}}$ & $98.04(8)$ \\
\hline $\mathrm{Ru}-\mathrm{O} 14$ & $1.956(6)$ & N11-Ru-O13 & $89.56(6)$ \\
\hline $\mathrm{Ru}-\mathrm{O} 31^{\mathrm{ii}}$ & $2.656(7)$ & N11-Ru-O14 & $87.66(7)$ \\
\hline $\mathrm{O} 31^{\mathrm{ii}}-\mathrm{Ru}-\mathrm{O} 14$ & $86.875(6)$ & N12-Ru-O13 & $90.67(6)$ \\
\hline $\mathrm{O} 32^{\mathrm{ii}}-\mathrm{Ru}-\mathrm{O} 13$ & $84.700(6)$ & N12-Cu-O14 & $91.22(6)$ \\
\hline $\mathrm{O} 32^{\mathrm{iii}}-\mathrm{Ru}-\mathrm{O} 14$ & $95.83(6)$ & $\mathrm{O} 31^{\mathrm{ii}}-\mathrm{Ru}-\mathrm{N} 12$ & $94.98(5)$ \\
\hline \multicolumn{4}{|l|}{ Complex 4} \\
\hline Ru-N1 & $2.070(3)$ & N1-Ru-O11 & $89.4(4)$ \\
\hline $\mathrm{Ru}-\mathrm{O} 3^{\mathrm{iv}}$ & $2.601(4)$ & $\mathrm{N} 1-\mathrm{Ru}-\mathrm{O} 3^{\mathrm{iv}}$ & $96.03(6)$ \\
\hline Ru-O11 & $1.943(6)$ & $\mathrm{O} 3^{\mathrm{iv}}-\mathrm{Ru}-\mathrm{O} 11$ & $88.23(2)$ \\
\hline
\end{tabular}

${ }^{k}$ Symmetry transformation used to generate equivalent atoms: (i) $-x, 1-y,-z$. 
Table 6. Antimicrobial activities of the complexes at $1.50 \mathrm{mg} \mathrm{L}^{-1}$

\begin{tabular}{|c|c|c|c|c|c|c|c|c|c|}
\hline \multirow{3}{*}{ Comlpex No } & \multicolumn{9}{|c|}{ Diameter of the inhibition zone in $\mathrm{mm}^{a b}$ (activity index) ${ }^{c}$} \\
\hline & \multicolumn{3}{|c|}{ Gram positive bacteria } & \multicolumn{3}{|c|}{ Gram negative bacteria } & \multicolumn{3}{|c|}{ Fungal strains } \\
\hline & S. aureus & \multicolumn{2}{|c|}{ B. cereus $P$. aeruginosa, } & S. enteritidis & \multirow{2}{*}{$\frac{\text { E. coli }}{9(0.78)}$} & \multirow{2}{*}{$\frac{K . \text { pneumonia }}{8(0.67)}$} & \multicolumn{3}{|c|}{ A. bisporus A. arvalis A.herbida } \\
\hline 1 & $15(0.37)$ & $12(0.28)$ & $13(0.83)$ & $7(0.47)$ & & & $8(0.73)$ & $10(0.73)$ & $12(0.33)$ \\
\hline 2 & $24(0.66)$ & $19(0.64)$ & $22(0.67)$ & $17(0.61)$ & $4(0.33)$ & $6(0.52)$ & $12(0.62)$ & $14(0.84)$ & $9(0.69)$ \\
\hline 3 & $6(0.58)$ & $7(0.56)$ & $10(0.62)$ & $8(0.72)$ & $11(0.53)$ & $9(0.41)$ & $7(0.38)$ & $15(0.66)$ & $13(0.74)$ \\
\hline 4 & $8(0.52)$ & $11(0.58)$ & $11(0.22)$ & $7(0.94)$ & $13(0.41)$ & $10(0.84)$ & $9(0.24)$ & $13(0.32)$ & $13(0.31)$ \\
\hline \multicolumn{2}{|c|}{ Cephalothin 27} & 30 & 28 & - & - & - & - & - & - \\
\hline \multicolumn{2}{|c|}{ Chloramphenicol - } & - & - & 25 & 29 & 30 & - & - & - \\
\hline \multicolumn{2}{|c|}{ Cycloheximide } & - & - & - & - & - & 27 & 29 & 30 \\
\hline
\end{tabular}

${ }^{a}$ Calculated from 3 values; ${ }^{b}$ Identified depending on morphological and microscopical characteristics. Low activity $=$ mean of zone diameter $\leq 0.33$ of mean zone diameter of reference. Moderate activity $=$ mean of zone diameter $\quad 0.33 \leq 0.66$ of the reference compound. High activity = mean of zone diameter $\geq 0.67$ of the mean zone diameter of the reference compound; ${ }^{c}$ Activity index : inhibition zone of the sample / inhibition zone of the reference compound.

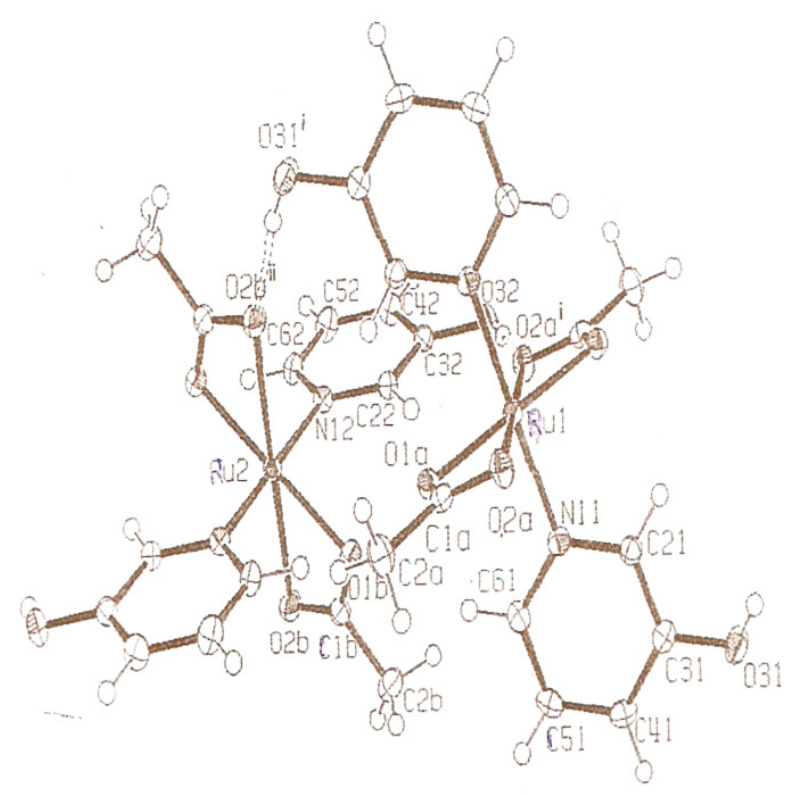

Figure 1. Crystal structure of the monomeric complex molecule of $\left[\mathrm{Ru}\left(\mathrm{O}_{2} \mathrm{CCH}_{3}\right)_{2}(\mathrm{py}-\mathrm{OH})_{2}\right]$, 1, with labelling of nonhydrogen atoms of asymmetrical unit 


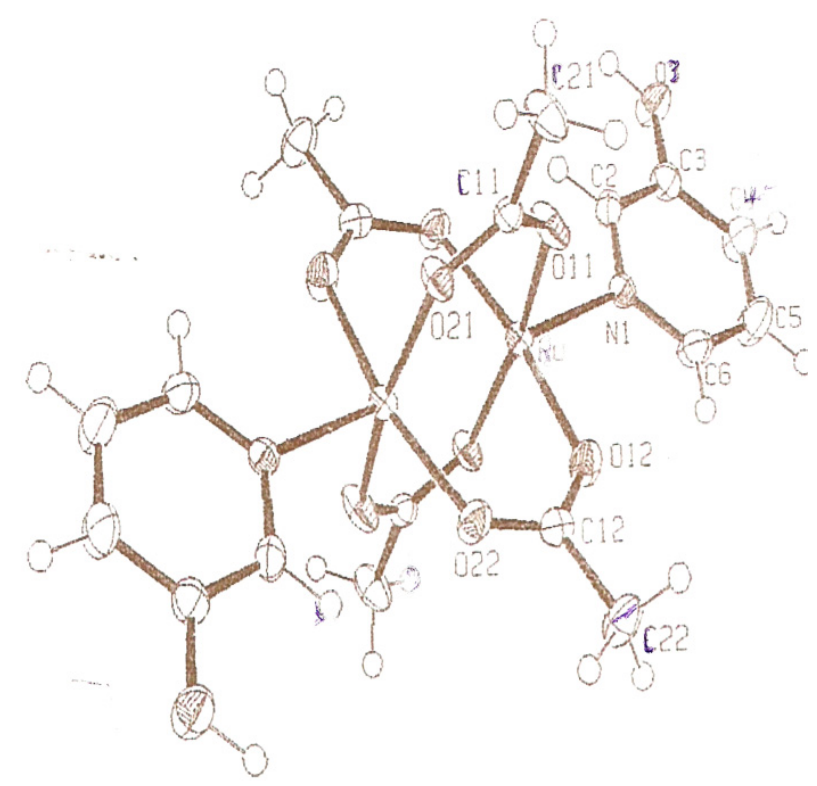

Figure 2. Crystal structure of dimeric molecule of $\left[\mathrm{Ru}_{2}\left(\mathrm{O}_{2} \mathrm{CCH}_{3}\right)_{4}(3-\mathrm{py}-\mathrm{OH})_{2}\right]_{2}$ with labelling of the non-hydrogen atoms of asymmetrical unit

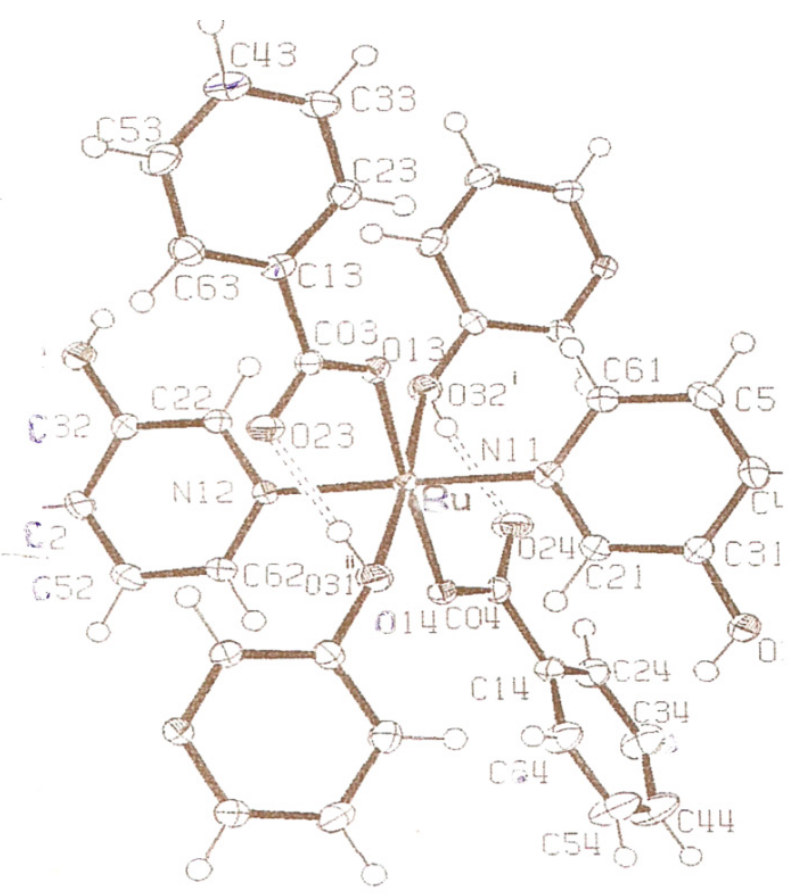

Figure 3. A view of the complex $\left[\mathrm{Ru}_{2}\left(\mathrm{O}_{2} \mathrm{CC}_{6} \mathrm{H}_{5}\right)_{2}(3-\mathrm{py}-\mathrm{OH})\right]_{\mathrm{n}}$ 


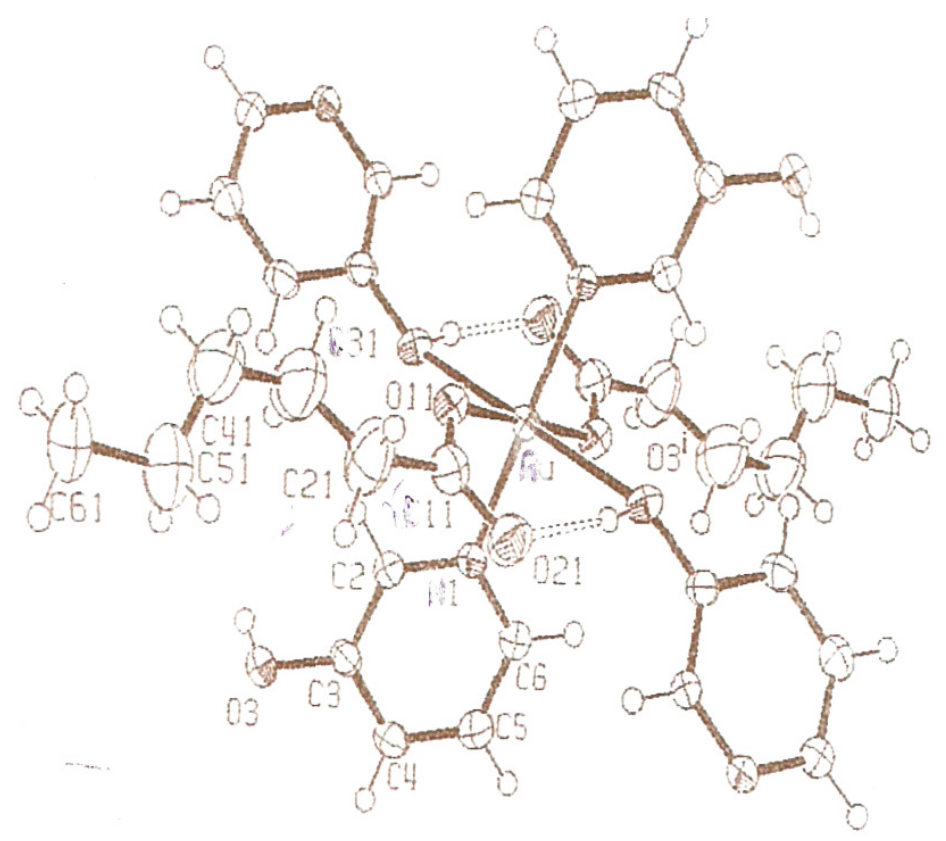

Figure 4. Crystal structure of complex molecule of $\left.\left[\mathrm{Ru}\left(\mathrm{O}_{2}\right) \mathrm{CCH}_{3}\left(\mathrm{CH}_{2}\right)_{4}\right)_{2}(3-\mathrm{pyOH})_{2}\right]_{\mathrm{n}}, 4$ 